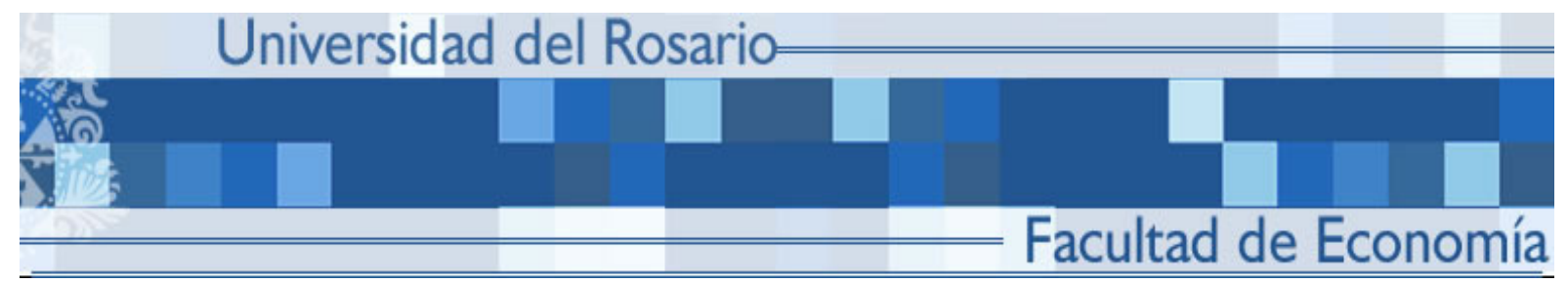

LEARNING HOW (NOT) TO FIRE A GUN: COMBATANT TRAINING AND CIVILIAN VICTIMIZATION

Ben Oppenheim

Juan Vargas

Michael Weintraub

SERIE DOCUMENTOS DE TRABAJO

No. 117

Diciembre 2011 


\title{
Learning How (Not) to Fire a Gun: Combatant Training and Civilian Victimization*
}

\author{
Ben A. Oppenheim¹, Juan F. Vargas², and Michael Weintraub ${ }^{3}$ \\ ${ }^{1}$ Department of Political Science, University of California-Berkeley, \\ benoppenheim@berkeley.edu \\ ${ }^{2}$ Department of Economics, Universidad del Rosario, \\ juan.vargas@urosario.edu.co \\ ${ }^{3}$ Department of Government, Georgetown University, \\ mlw63@georgetown.edu
}

December 6, 2011

\begin{abstract}
What is the relationship between the type of training combatants receive upon recruitment into an armed group and their propensity to abuse civilians in civil war? Does military training or political training prevent or exacerbate the victimization of civilians by armed non-state actors? While the literature on civilian victimization has expanded rapidly, few studies have examined the correlation between abuse of civilians and the modes of training that illegal armed actors receive. Using a simple formal model, we develop hypotheses regarding this connection and argue that while military training should not decrease the probability that a combatant engages in civilian abuse, political training should. We test these hypotheses using a new survey consisting of a representative sample of approximately 1,500 demobilized combatants from the Colombian conflict, which we match with department-level data on civilian casualties. The empirical analysis confirms our hypotheses about the connection between training and civilian abuse and the results are robust to adding a full set of controls both at the department and at the individual level.
\end{abstract}

Keywords: civil war, civilian abuse, survey instrument, demobilized combatants JEL: D74

*The authors thank Juan Carlos Palou and María Victoria Llorente at Fundación Ideas para la Paz for generously sharing their survey data and Dario Romero for excellent research assistance. 
"Especially at the beginning, we made mistakes, since we had poor training. But we have matured as a fighting force..." Carlos Castaño, former leader of the paramilitary group Autodefensas Unidas de Colombia (AUC), admitting to what he calls mistakes: the killing of innocent civilians (quoted in Kirk, 1998).

\section{Introduction}

Civil wars are fought "among the people," given that "military engagements can take place anywhere, with civilians around, against civilians, in defence of civilians" (Smith, 2005). As a result, noncombatants suffer significant violence, both in the form of collateral damage and deliberately targeted attacks (Slim, 2010). Epidemiological estimates suggest that over the course of the twentieth century, civilian casualties rose from ten to up to ninety percent of total wartime casualties (Garfield and Neugut, 1997; Eck and Hultman, 2007); more conservative metrics indicate that while the share of civilian casualties has declined from the heights of the Cold War - estimated at fifty percent of total casualties - the figure remains significant, at an average of more than 20 percent of total casualties (Melander, Öberg and Hall, 2009).

Scholars and policymakers have increasingly grappled with the causes of civilian victimization during war. Recent research has shown that there is tremendous variation in the extent to which armed groups deliberately attack civilians, both within wars (Balcells, 2010), and across conflicts (Downes, 2006). Attempts to explain this variation have followed two broad research agendas. The first agenda has sought to understand the impact of contextual factors such as the political advantages conferred on civilians for providing intelligence on opponents (Kalyvas, 2006; Balcells, 2010), and the military advantages conferred on armed groups by killing civilians (Valentino, Huth and Balch-Lindsay, 2004). The second agenda

has focused on the "industrial organization" of armed groups, including the capacity of armed 
groups to discipline and sanction foot soldiers (Humphreys and Weinstein, 2006; Johnston, 2008; Beber and Blattman, n.d.), and the differing types of recruits attracted by groups flush with or starved for resources (Weinstein, 2006). ${ }^{1}$

In this article, we contribute to the latter agenda by exploring a critical but understudied component of the industrial organization of armed groups: training and indoctrination. Training is a critical determinant of military behavior in wartime. It influences not only the effectiveness with which armed groups use force, but how, where, and against whom they employ violence. Lack of training is likely to increase the odds that civilian populations will suffer from collateral damage, and to lead to the deliberate targeting and killing of civilians. Moreover, current military doctrine suggests that these effects should be strongest in irregular wars in which military units operate among civilian populations: the US Army/Marine Corps Counterinsurgency Field Manual argues that "poorly trained leaders and units are more prone to committing human rights violations than well-trained, well-led units. Leaders and units unprepared for the pressure of active operations tend to use indiscriminate force, target civilians, and abuse prisoners" (The U.S. Army/Marine Corps Counterinsurgency Field Manual, 2007, 6-13).

Do combatants who receive training upon recruitment into civil war exhibit a lower propensity to kill civilians? In order to shed light on this question, we first distinguish between two distinct forms of training: military and political/doctrinal. Second, we present a very simple partial equilibrium formal model of the incentives combatants face to kill civilians, and argue that political indoctrination lowers the likelihood that combatants will do so. In contrast, the model suggests that military training is not likely to reduce the probability

\footnotetext{
${ }^{1}$ The literature on civilian victimization is vast. Relevant contributions that do not focus on training include Hoeffler and Azam (2002), Valentino, Huth and Balch-Lindsay (2004), Kalyvas (2006), Weinstein (2006), Humphreys and Weinstein (2006), Herreros and Criado (2009), Vargas (2009), Wood (2010), Metelits (2008, 2010), Slim (2010), Balcells (2010), Cohen (2010), among many others. For scholarship that addresses the conditions under which states and occupying powers commit abuses against civilians, see Kahl (2007), Leiby (2009), Condra et al. (2011).
} 
that a combatant will target civilians with violence. Third, we test the model's predictions empirically, using a survey of 1,500 demobilized guerrilla and paramilitary fighters from the Colombian conflict, carried out by Fundación Ideas para la Paz (FIP), a Colombian nongovernmental organization. The survey provides a representative sample of the combatants population, and includes information on ex-combatants' modes of training and their locations across time. We match ex-combatants' locations with department-level data on civilian fatalities from Restrepo, Spagat and Vargas (2004) to estimate the effect of military and political/doctrinal of training on civilian casualties, while controlling for confounding factors. Our statistical results confirm our hypotheses, and are robust to the inclusion of a battery of department and individual-level control variables, as well as to the use of alternate regression techniques.

This study makes several contributions to the literature. By focusing on training, we identify and begin to theorize an important dimension of the internal organization and functioning of armed groups. We disaggregate training into several conceptually distinct dimensions, and test the impact of each on the prevalence of civilian killings. Finally, we underline the potential contribution of individual-level survey data to our understanding of the dynamics of civil war. To the best of our knowledge, only one other study (Humphreys and Weinstein, 2006) uses individual-level survey data of former combatants to assess the correlates of civilian victimization, even though such data provide a powerful opportunity to systematically explore the factors which motivate (or mitigate) the killing of civilians.

This paper proceeds as follows. The next section connects training to civilian victimization. The third section presents a simple model that formalizes the relationship between different kinds of training and variation in civilian casualties. The fourth section presents the data and explains our research design. The fifth section explores the statistical results. The final section discusses the implications of our findings and concludes. 


\section{Learning How (Not) to Fire a Gun}

Doctrine and policy guidance on training within professional armed forces stresses the connection between discipline gained through rigorous training and indoctrination, and restraint exercised in dealing with civilian populations, especially during counterinsurgency operations (Small Wars Manual: United States Marine Corps, 1940; The U.S. Army/Marine Corps Counterinsurgency Field Manual, 2007). The process and content of training varies widely within and across military organizations. However, it is possible, and we argue critical, to distinguish between two dimensions of warfighting, and hence, training: the production and application of coercive force, on the one hand, and the management of force, or decisions regarding where and how coercion should be utilized, on the other (Huntington, 1957, 13; The U.S. Army/Marine Corps Counterinsurgency Field Manual, 2007, 6-14). The former requires military and operational training, the latter exposure to doctrine.

The production and application of force requires a range of mechanical, technical, and organizational skills. The content of training is correspondingly broad: soldiers are taught to effectively use weapons, to maintain equipment, to execute a wide range of tactics and maneuvers, and to operate smoothly within larger units. The process of military training serves an equally important set of latent functions: to acclimate soldiers to follow orders and maintain discipline, and to build trust, cohesion, and coordination within and among units (The U.S. Army/Marine Corps Counterinsurgency Field Manual, 2007; Brooks, 2007, 1-6).

The second dimension of training, exposure to military doctrine, concerns the management of force. Avant argues that doctrine "falls between the technical details of tactics and the broad outline of grand strategy. Whereas tactics deals with issues about how battles are fought, doctrine encompasses the broader set of issues about how one wages war" (Avant, 1993). Doctrine is not designed to tightly script the actions of soldiers, but instead provides a body of knowledge, principles, and policies in order to inform the decision-making of soldiers 
in the field (Janowitz, 1959). Doctrine, particularly in irregular and civil conflict, emphasizes the centrality of the relationship between combatants and civilians.

Both classical and contemporary counterinsurgency doctrines assume - perhaps uncritically - that insurgents and their opponents are struggling for the support of a largely undecided public (Biddle, 2008). For insurgents, public support provides a flow of resources, recruits, information, and cover. For counterinsurgents, civilians are the sole source of local intelligence necessary to sift insurgents from the population. Although insurgents may rely upon coercion to compel civilian support, classical models of insurgency emphasize inducement over coercion, and the careful inculcation of a trusted, cooperative relationship between soldiers and civilians (Tse-Tung, 1937). Counterinsurgency, as the mirror image of insurgent doctrine, matches this intent (Kilcullen, 2006/7). In order to form trusted ties with civilians, insurgents and counterinsurgents first attempt to avoid sins of commission. Doctrine attempts to limit civilian casualties by guiding soldiers to utilize discriminate and proportionate force, and to respect laws of war which limit the exposure of civilians to violence (The U.S. Army/Marine Corps Counterinsurgency Field Manual, 2007).

Although training is conventionally understood to depress civilian casualties, we argue that training consists of two distinct components, and that political indoctrination rather than military training is the causal driver of this effect.

\section{Does Training Affect Civilian Victimization?}

\section{A Simple Analytical Framework}

There are many ways that armed groups may encourage soldiers to exercise restraint in the conduct of military operations. In this section we use a simple formal model to consider the incentives facing individual combatants to abuse civilians given two types of training received: military training and political training. 
Consider a continuum of mass 1 of combatants, indexed by $i$, who fight for the control of a disputed territory of value $R$. Each combatant $i$ has to choose his fighting strategy from a portfolio that comprises both classical military actions or targeting civilians thought to support the enemy. Hence the combatant can choose between military effort, $e_{M}$, or targeting effort, $e_{T}$. Both fighting efforts are costly and we note the the cost of effort as $c\left(e_{f}\right)$, with $f=\{M, T\}$.

Combatant $i$ must then choose his combat strategy and for that he compares the expected utility of exerting classical military actions and targeting civilians. ${ }^{2}$ His expected payoff from exerting military effort is:

$$
\left.U^{i}\left(e_{M}\right)=\alpha p\left(\sum_{i} e_{M}^{i}, \sum_{i} e_{T}^{i}\right)\right) R-c\left(e_{M}\right)
$$

where $p()$, the probability that combatant $i$ 's group gains control of the $R$-valued territory, depends on the aggregate military and targeting effort of all the group's combatants. Moreover, this probability is shifted by a group efficiency parameter $(\alpha>0)$ which is an increasing function of the fraction of group combatants who have received military training $\left(\alpha=\sum_{i} \alpha^{i}\right)$. In other words, military training of individual group members increases group-wide chances of winning the contest.

On the other hand, $i$ 's expected payoff of targeting the alleged civilian infrastructure of the enemy is:

$$
\left.U^{i}\left(e_{T}\right)=\alpha p\left(\sum_{i} e_{M}^{i}, \sum_{i} e_{T}^{i}\right)\right) R-\gamma^{i} c\left(e_{T}\right)-\sigma^{i}
$$

where $\sigma^{i}$ is individual $i$ 's exogenous idiosyncratic disutility from killing civilians. While some combatants may have no regret in killing non-combatants in the fight for territorial control $\left(\sigma^{i}=0\right)$, others may have higher moral standards and experience a disutility when engaging

\footnotetext{
${ }^{2}$ We assume that $i$ has to choose only one option and cannot combine both forms of fighting.
} 
in such a practice $\left(\sigma^{i}>0\right)$. In addition, we do not rule out the existence of savage combatants who actually enjoy killing unarmed civilians $\left(\sigma^{i}<0\right)$. More generally, we assume $\left(\sigma^{i}\right)$ is distributed across combatants according to some probability density function $f\left(\sigma^{i}\right)$.

Note that equation (2) features an additional individual-level parameter. In contrast to the moral-driven disutility of killing civilians $\left(\sigma^{i}\right), 0<\gamma^{i}<1$ is endogenous and depends positively on the amount of political training combatant $i$ has received. Hence, combatants who have received more political indoctrination perceive targeting civilians as individually more costly because they are aware that this hurts the legitimacy of their group $(\gamma \rightarrow 1)$. Combatants that have had little or no political training don't perceive such a high cost $(\gamma \rightarrow 0)$. Assuming that different combatants have different degrees of political training gives us a source of heterogeneity.

Because combatant $i$ has to decide whether to exert military or targeting effort, given (1) and (2) his objective function is formally:

$$
\max _{I=\{0,1\}} I\left[\alpha p R-c\left(e_{M}\right)\right]+(1-I)\left[\alpha p R-\gamma^{i} c\left(e_{T}\right)-\sigma^{i}\right]
$$

Note that the choice of targeting civilians $(I=0)$ is taken as long as:

$$
\alpha p R-\gamma^{i} c\left(e_{T}\right)-\sigma^{i}>\alpha p R-c\left(e_{M}\right)
$$

which can be written as:

$$
\sigma^{i}<c\left(e_{M}\right)-\gamma^{i} c\left(e_{T}\right)
$$

As in the standard probabilistic voting model (Lindbeck and Weibull, 1987; Persson and Tabellini, 2000), we assume for simplicity an explicit functional form of $f\left(\sigma^{i}\right)$. Let $\sigma^{i}$ be distributed uniformly in the domain $\left[-\frac{1}{2 \phi}, \frac{1}{2 \phi}\right]$, where $\phi$ is the density of the distribution. Hence, the equilibrium share of combatants that end up targeting civilians is: 


$$
\begin{aligned}
N_{T} & =\int_{-\infty}^{c\left(e_{M}\right)-\gamma^{i} c\left(e_{T}\right)} f\left(\sigma^{i}\right) d i \\
& =\int_{-\frac{1}{2 \phi}}^{c\left(e_{M}\right)-\gamma^{i} c\left(e_{T}\right)} \phi d i \\
& =\frac{1}{2}+\phi\left[c\left(e_{M}\right)-\gamma^{i} c\left(e_{T}\right)\right]
\end{aligned}
$$

This equation suggest that the fraction of combatants who target civilians is a function of the differential cost of effort as well as $\phi$, the density if $f\left(\sigma^{i}\right)$.

Some comparative statics of interest emerge from this simple expression. On the one hand $\frac{\partial N_{T}}{\partial \gamma^{i}}<0$. That is, greater political training for combatant $i$ decreases the fraction of fighters who target civilians and hence decreases the number of civilians killed (which we naturally assume increasing in the fraction of victimizers). Note however that $\frac{\partial N_{T}}{\partial \alpha^{i}}=0$ and thus, in this simple framework, military training does not affect civilian victimization. The intuition is at follows: military training increases the probability that groups win the contest. This probability shift is, critically, group-wide not individual-specific, and hence is present in both the utility from performing a classical military action (equation 1) and that of targeting civilians (equation 2), so it cancels out in the individual-level comparison of payoffs. Indeed, it is groups, not individuals, who win violent contests. On the other hand, political training does affect the preferences of individual combatants by shifting the cost of victimizing the civilian population.

Given these findings from our formal model, we now present our two hypotheses:

H1: Military training does not decrease the probability that a combatant engages in civilian abuse.

H2: Political training does decrease the probability that a combatant engages in civilian abuse. 
The next section introduces our data, gleaned from a survey of demobilized combatants in Colombia.

\section{Testing the Link Between Training and Civilian Vic- timization: Research Design}

Between 2002 and 2008, more than 45,000 combatants in Colombia disarmed, demobilized, and reintegrated into civilian life. These ex-combatants were drawn from both leftist rebel groups such as the Fuerzas Armadas Revolucionarias de Colombia (FARC) and Ejército de Liberación Nacional (ELN), as well as right-wing paramilitary units known as the Autodefensas Unidas de Colombia (AUC). The leftist rebels demobilized through a slow, individual process of demobilization following defections from the guerrilla ranks in the context of an escalation of government counterinsurgent initiatives following the election of Álvaro Uribe in 2002. In contrast, the paramilitaries demobilized collectively, en masse, following a bilateral peace process with the government initiated in 2003.

The incentives provided by the government for demobilization included access to social services, education and training, cash assistance, support to initiate productive projects, and reduced prison terms. Following the establishment of the High Commission for Reintegration - in Spanish, la Alta Consejería para la Reintegración or ACR - in 2006, both guerrillas who demobilized individually and paramilitaries who gave up arms collectively began to receive identical benefits in exchange for demobilization.

The survey data we use to test our hypotheses were collected by Fundación Ideas para la Paz (FIP), a Colombian non-governmental organization founded in 1999. The survey, composed of 1,500 demobilized combatants, was administered to a representative sample of the entire population of demobilized combatants between February 5, 2008 and May 31, 2008 in various regions across Colombia. More specifically, interviewers conducted the survey 
on the Caribbean Coast (except Córdoba and Sucre), in Antioquia (except Urabá), Valle y Cauca, Nariño, and in Bogotá.

The FIP survey asked respondents an array of questions related to their behavior prior to entering the armed group, the context and incentives that drove their recruitment, their experience while in the armed group, their decision to exit the armed group, and finally their well-being and economic status following demobilization and the provision of demobilizationrelated benefits.

The survey does not, however, provide a thorough account of the kinds of armed actions combatants took against civilians during the course of combat. The only variable related to civilian abuse, with which we begin our analysis, concerns the ways that combatants obtained goods from the civilian population. As is well established in the literature on survey design, individuals are likely to underreport participation in behaviors that are, or are seen to be, immoral or criminal, so the omission of such questions from the survey is not surprising. ${ }^{3}$ To assess the connection between training and civilian casualties, therefore, most of our models use a more objective (though aggregated) measure of civilian victimization, not garnered through survey responses. In particular, we use individual-level data taken from the FIP survey concerning a fighter's geographic location during his or her time in the armed group, as well as the years in which he or she was active in that group, and match those data to department-level civilian casualty data from Restrepo, Spagat and Vargas (2004). The civilian casualty data were coded using events listed in the periodicals Justicia y Paz and Noche y Niebla, published quarterly by two Colombian non-governmental organizations, El Centro de Investigación y Educación Popular (CINEP) and the Comisión Intercongregacional de Justicia y Paz. The data are now maintained by CERAC, a Bogotá-based think

\footnotetext{
${ }^{3}$ Common strategies to shield respondents from culpability and to obtain accurate estimates of engagement in such behavior include the use of the Unmatched Count Technique (UCT) or list questions. On the methodological benefits of using these techniques, see Coutts and Jann (2009). For an empirical example, see Gueorguiev, Malesky and Jensen (2011).
} 
tank. ${ }^{4}$ Figures 1 and 2 visually display the distribution of armed group activity and civilian casualties, respectively, across departments in Colombia using these data.

The research design described above entails a critical assumption: that the interviewed demobilized combatant is representative of other combatants in that same group within the same region. More specifically, for our purposes, we assume that the kind of training he or she received is the same as that received by an individual within the same armed group in the same department during the same period of activity. We believe that this is a reasonable assumption, given that rarely do there exist multiple fronts of the same group within the same department at a given point in time, and even if there were multiple fronts, these must have had very distinct training protocols to invalidate our inference.

In estimating our models, we control for a variety of confounding factors, including department-level variables that are likely to affect the level of civilian casualties, as well as individual-level characteristics obtained in survey responses from demobilized combatants. The department level controls, described in detail below, are grouped into five different categories: geographic characteristics, conflict variables, economic attributes of the area, institutional presence and, finally, a municipal scale control.

First, we use geographic variables to insure that civilian casualties are not being driven by climatological or topographical peculiarities of individual departments. These geographic variables are the department's area, average elevation, average rainfall, soil quality and erosion, and an index of water availability. Second, we use measures of conflict incidence to control for the dynamics of the armed group activity, as well as counterinsurgency operations, in each department. More specifically, we use the number of attacks from each armed group, the number of clashes between illegal groups and the government, and the average murder rate in the department. Third, we use two economic variables that might drive armed

\footnotetext{
${ }^{4}$ For much greater detail on coding methodology and patterns of violence in Colombia's internal armed conflict, see Restrepo, Spagat and Vargas (2004).
} 
group activity and civilian targeting. Our models include the average of the Unsatisfied Basic Needs poverty index and the Gini coefficient for each department in Colombia. Fourth, we use measures of institutional presence to ensure that the number of civilian casualties is not being driven by the absence of state authority or institutions. Our institutional presence variables include the per capita number of courts, attorney offices and prosecutor offices in a given department. Finally, we include population as a municipal scale control.

In addition to the department-level control variables, we also include individual characteristics such as the age of the fighter, the combatant's age at the time of recruitment, as well as an indicator of which illegal armed group the fighter belonged to.

Table 1 provides summary statistics for all variables used in our regressions. Table 2 reports cross-tabulations of the three principal training variables we use: generic training, military training, and political training. Although there is a high correlation between having received generic training and military training, the correlation between military training and political training is relatively modest at 0.265 , alleviating concerns that we would be unable to distinguish between the effects of these two variables on our outcome of interest.

Finally, Figures 3, 4, and 5 provide frequency histograms for each of these types of training, disaggregated by armed group.

\section{$5 \quad$ Results and Robustness Checks}

To begin the statistical analysis, we consider individual respondents' answers to the only question in the FIP survey that directly addresses civilian abuse. The survey instrument asks ex-combatants how they obtained consumption goods, such as food, for their group. ${ }^{5}$ The interviewer then provided an option, such as "I bought them," and waited for a response, then provided another option, such as "they were given by peasants." Respondents were free

\footnotetext{
${ }^{5}$ In Spanish the question reads “¿Cómo obtenía los bienes de consumo (ej. Comida) su Frente?”
} 
to answer "yes" to as many of these options as they wished. Three response options involve the use of force: goods were taken by force from peasants; taken by force from merchants; and taken by force from landowners. We create dummy variables for each of these "taken by force" responses to test whether different kinds of training affects combatants' willingness to engage in such activities. The last column in each of the individual-level tables (Tables 3, 4 and 5) is a dummy variable that takes a value of 1 if a respondent answered yes to having taken goods by force from any of the three populations.

To test our hypotheses, we use a question from the FIP survey that asked "What type of training did you receive?"6 which then provided possible responses including military and political/ideological training, among others. Respondents could answer "yes" to all, some, or none of these options. We constructed dummy variables for each of the survey-specified options. All of the individual-level models in Tables 3, 4, and 5 use the Ordinary Least Squares estimator.

We start by assessing how generic training - not disaggregated by military or political training - affects combatants' willingness to take goods by force. To control for confounding factors, we include variables for gender, the first group that the individual joined, and the combatants' age at the time of recruitment. We can see from Table 3 that generic training is only significant when using the goods "taken from landowners" dependent variable. Receiving generic training appears to increase the likelihood that an individual engaged in such behavior. In none of the other three models in Table 3, however, does the generic training variable reach statistical significance.

We now turn to the effect of military training on individuals' likelihood of taking goods by force. From the results in Table 4 we can see that the military training variable does not reach statistical significance in any of the models. As predicted by our theory, there appears to be no connection between receiving military training and taking goods by force

\footnotetext{
${ }^{6}$ In Spanish, the question reads, "¿Qué tipo de entrenamiento recibió?"
} 
from civilians.

Table 5 assesses the effect of political training on taking goods by force from civilians. We find that political training is statistically significant and negative in two of the four models: political training reduces the likelihood that combatants stole from peasants, but had no effect on taking goods by force from merchants and landowners. The political training variable also reaches statistical significance in the final column which captures whether goods were taken by force from any of the three populations. Given these results, we find qualified support for our hypotheses using individually-reported instances of abuse against civilians: military training has no effect upon civilian abuse, while political training does, at least in some models. However, as mentioned in the previous section, individuals are likely to underreport participation in behaviors that are, or are seen to be, immoral or criminal. Thus we now turn to the civilian casualty data to more fully evaluate our key hypotheses.

Using the data for conflict-related civilian casualties at the departmental level from Restrepo, Spagat and Vargas (2004) as our dependent variable, we begin with a bivariate model using the generic training question. ${ }^{7}$ As reported in Table 6 , in a bivariate model, the generic training variable is positively associated with civilian casualties and the association is statistically significant. However, as we begin to include additively the department-level controls, this result does not hold. Once the full range of department and individual level controls are included, the sign on the generic training variable flips, and most importantly it is no longer statistically significant. Our hypotheses treated military and political training separately, and we should therefore expect different results for each. We now turn to models that address these hypotheses explicitly. ${ }^{8}$

\footnotetext{
${ }^{7}$ Results from models in Tables 6, 7, 8, 9, and 10 are nearly identical (both in terms of sign and significance as well as in terms of substantive magnitude) when fitting a negative binomial event count estimator. In the paper we stick to OLS estimates because, as argued by Angrist and Pischke (2008), OLS is the best linear approximation to the actual conditional expectations function, while non linear models are very sensitive to model specification. Negative binomial results are available upon request.

${ }^{8}$ In addition to military and political training the generic training question encompasses things like finance, propaganda, communications, administrative and intelligence training.
} 
Table 7 assesses the effect that the individual military training of a representative excombatant has on civilian casualties at the department level. Our first hypothesis stipulates that we should not expect a correlation between military training and civilian casualties. We can see that in a bivariate model military training is positive and significant. Yet when we include the controls in an additive fashion the variable does not retain statistical significance, and the sign flips. In particular, once we include the full range of department-level and individual-level controls, in model 7 , we see that there is no statistically significant relationship between military training and civilian casualties. Our first hypothesis finds support when using the civilian casualty data.

We next examine the relationship between political training and civilian casualties, in Table 8. In a bivariate model, the political training variable is negative but not statistically significant. Once we successively add in departmental control variables, however, the effect turns significant and statistical significance is retained across all models. Although the magnitude of the effect varies among the models, political training shows a clear, negative effect upon civilian casualties across multiple model specifications. Combatants who receive political training abuse civilians less than those who do not receive political training, ceteris paribus.

To calculate the substantive effect of political training on civilian casualties, we use Clarify (King, Tomz and Wittenberg, 2000). ${ }^{9}$ Setting all the controls at their median value, when the political training dummy changes from zero to one the department-level predicted number of civilian casualties drops by $5.99 \% .^{10}$

The dependent variable for the majority of our models, an incident count of civilian killings compiled by Restrepo, Spagat and Vargas (2004), provides a high-frequency, longitudinal measure of violence. However, it does not measure other forms of violence against

\footnotetext{
${ }^{9}$ All predicted probabilities are obtained using estimates from model 7, the fully-specified model.

${ }^{10}$ The dummy variables for group membership in these simulations are all held at one.
} 
civilians, such as non-lethal violence, intimidation, or harassment. As a result, the models presented above may underestimate the overall impact of training on civilian victimization by focusing only on its most drastic observable form. In particular, we may underestimate the effect of political training on civilian casualties: while military training is not designed to influence the propensity of fighters to harass, intimidate, or injure civilians, indoctrination may be configured to reduce these behaviors.

We now turn to the subsample of paramilitary combatants from the survey respondents. We do so to check for potential selection bias in the full sample. Recall that leftist guerrilla fighters demobilized individually after deserting from their fronts. As such, there is a chance that although the FIP sample is representative of the entire population of demobilized fighters, the population of combatants who demobilized individually may have had a different propensity to abuse civilians than the total population of combatants. More specifically, it is possible that combatants who choose to demobilize are those least likely to have abused civilians regardless of the training they received, which would downwardly bias our results. Given that the paramilitaries demobilized collectively, in the context of a peace process, there is much less possibility of selection bias affecting our findings when we restrict the sample to former paramilitary combatants.

The results from regressing political training on civilian casualties within the paramilitary subsample are reported in Table 9. The findings confirm and strengthen those in the broader combatant sample. Political training significantly reduces civilian casualties. In a bivariate model the training variable is positive and statistically significant, but the sign switches once departmental controls are added. The training variable achieves statistical significance in model 4 and retains statistical significance with the successive addition of departmental and individual-level control variables in models 5, 6, and 7 .

As above, we calculate the substantive effect of political training among paramilitaries on 
civilian casualties. ${ }^{11}$ Setting all the controls at their median value, when the political training dummy changes from zero to one, the department-level predicted number of civilian casualties drops by $6.61 \% .^{12}$ The results linking political training to civilian casualties are even stronger in the paramilitary sub-sample, which suggests that our estimates in the broader sample were, indeed, likely downwardly biased, and that the connection between political training and civilian casualties is even stronger than that reported from the full sample in Table 8 .

Individuals' reasons for joining an armed group may have an effect on their propensity to use violence (Weinstein, 2006). Table 10 examines models with interaction terms to see whether the effect of training on civilian victimization varies across the different reasons why combatants joined armed groups. These tests are again carried out on the subsample of paramilitary combatants to guard against selection bias. Respondents were asked why they joined the armed group and were provided a list of reasons that included the promise of material benefits, to improve the situation in Colombia, and to engage in revenge. We create dummy variables for each of these responses and, in separate models, interact each with the political training variable. The results in Table 10, which present models with the standard battery of controls, show that political training remains significant in all models. As for the interaction with the dummies for the reason of joining, only that of political training with "joined because promised material benefits" is statistically significant (and positive), and this is so both in the model that includes only that reason (first column) as well as in the model that includes all reasons simultaneously (last column). This suggests that the negative effect that political training has on civilian casualties - reducing their numbers - is mitigated when individuals joined the paramilitary group for material reasons. This result resonates with the finding of Weinstein (2006) that groups that use material incentives to attract recruits are

\footnotetext{
${ }^{11}$ All predicted probabilities are obtained using estimates from model 7 , the fully-specified model, in Table 9 .

${ }^{12}$ The dummy variables for group membership in these simulations are all held at zero for guerrilla groups and one for the AUC.
} 
more likely to abuse civilians.

\section{Conclusion}

This paper contributes to a growing literature that looks within rebel groups to explain variation in their behavior and impact on civilian populations. Our research suggests that repertoires of political training and indoctrination within armed groups, a factor which has largely been ignored by scholars of civil war, helps explain variations in the use of deadly force against civilians. We present a simple analytical framework to hypothesize that lower levels of civilian casualties are correlated with political training and indoctrination, but not with military training. We then use regression techniques to isolate the effect that different types of training of rebel and paramilitary fighters have on civilian abuse and civilian fatalities.

The work that we have undertaken here is necessarily preliminary, but suggests that the conventional wisdom that training generically improves combatant behavior may not be correct. Instead, political training and indoctrination - processes which inform how, when, and why force should be utilized - appear to be doing the causal work. What is not known is precisely how: the specific content of doctrine could shape combatant behavior by proscribing the abuse of civilians, or the process of indoctrination itself could sensitize combatants to their relationship to civilian populations, resulting in more discriminate force. More research is necessary to identify and explore the specific causal channels driving this effect, and to see whether the relationship between training and civilian killing has external validity beyond the Colombian case.

The abuse of civilians in civil war is a pressing policy issue because of the human costs borne by non-belligerents caught up in conflict. Our results suggest several lessons. First and most simply, groups with no clear body of doctrine or process of political training are likely to present a greater threat to civilian safety than groups which politically train their fighters. 
Second, our initial results suggest that political training can mitigate, but not eliminate, the potential for excess civilian casualties generated by armed groups' recruitment strategies: groups which recruit through material incentives are likely to present a threat to civilians, even when political training is in place. 


\section{References}

Avant, Deborah. 1993. "The Institutional Sources of Military Doctrine: Hegemons in Peripheral Wars." International Studies Quarterly 37(4):409-430.

Balcells, Laia. 2010. "Rivalry and Revenge: Violence against Civilians in Conventional Civil Wars." International Studies Quarterly 54(291-313).

Beber, Bernd and Christopher Blattman. n.d. "The Logic of Child Soldiering and Coercion." Working Paper.

Biddle, Stephen. 2008. "The New U.S. Army/Marine Corps Counterinsurgency Field Manual as Political Science and Political Praxis." Perspectives on Politics 6(2):347-353.

Brooks, Risa A. 2007. Introduction: The Impact of Culture, Society, Institutions, and International Forces on Military Effectiveness. In The Sources of Military Effectiveness, ed. Risa A. Brooks and Elizabeth A. Stanley.

Cohen, Dara Kay. 2010. Explaining Sexual Violence During Civil War PhD thesis Stanford University.

Condra, Luke N., Joseph H. Felter, Radha K. Iyengar and Jacob N. Shapiro. 2011. "Insurgent Math: The Impact of Civilian Casualties in the Afghan Insurgency.".

Coutts, Elizabeth and Ben Jann. 2009. "Sensitive Questions in Online Surveys: Experimental Results for the Randomized Response Technique (RRT) and the Unmatched Count Technique (UCT)." General Online Research Conference in Vienna.

Downes, Alexander. 2006. "Desperate Times, Desperate Measures: The Causes of Civilian Victimization in War." International Security 30(4):152-195.

Eck, Kristine and Lisa Hultman. 2007. "One-Sided Violence against Civilians in War: Insights from New Fatality Data." Journal of Peace Research 44(2):233-246.

Garfield, Richard M. and Alfred I. Neugut. 1997. The Human Consequences of War. In War and Public Health, ed. Barry S. Levy and Victor W. Sidel.

Gueorguiev, Dimitar, Edmund Malesky and Nathan Jensen. 2011. "Rent(s) Asunder: How Sectoral Rent Extraction Probabilities Influence the Effect of Economic Openness on Corruption." Presented at UCSD Governance, Development, and Political Violence Workshop.

Herreros, Francisco and Henar Criado. 2009. "Pre-emptive or Arbitrary: Two Forms of Lethal Violence in a Civil War." Journal of Conflict Resolution 53(3):419-445.

Hoeffler, Anke and Jean-Paul Azam. 2002. "Violence Against Civilians in Civil War." Journal of Peace Research 39(4):461-485.

Humphreys, Macartan and Jeremy M. Weinstein. 2006. "Handling and Manhandling Civilians in Civil War." American Political Science Review 100(3):429-447. 
Huntington, Samuel. 1957. The Soldier and the State. Belknap Press of Harvard University Press.

Janowitz, Morris. 1959. "Changing Patterns of Organizational Authority: The Military Establishment." Administrative Science Quarterly 3(4):473-493.

Johnston, Patrick. 2008. "The Geography of Insurgent Organization and its Consequences for Civil Wars: Evidence from Liberia and Sierra Leone." Security Studies 17(1):107-137.

Kahl, Colin. 2007. "In the Crossare or the Crosshairs? Norms, Civilian Casualties, and U.S. Conduct in Iraq." International Security 32(1):7-46.

Kalyvas, Stathis N. 2006. The Logic of Violence in Civil War. Cambridge: Cambridge University Press.

Kilcullen, David. 2006/7. "Counterinsurgency Redux." Survival 48(4):111-130.

King, Gary, Michael Tomz and Jason Wittenberg. 2000. "Making the Most of Statistical Analyses: Improving Interpretation and Presentation." American Journal of Political Science 44(2):347361.

Kirk, Robin. 1998. "A Meeting with Paramilitary Leader Carlos Castano.”.

Leiby, Michele L. 2009. "Wartime Sexual Violence in Guatemala and Peru." International Studies Quarterly 53:445-468.

Lindbeck, Assar and Jörgen Weibull. 1987. "Balanced-Budget Redistribution as the Outcome of Political Competition." Public Choice 52:272-297.

Melander, Erik, Magnus Öberg and Jonathan Hall. 2009. "Are 'New Wars' More Atrocious? Battle Severity, Civilians Killed, and Forced Migration Before and After the Cold War." European Journal of International Relations 15(3):505-536.

Metelits, Claire. 2008. "The Consequences of Rivalry: Explaining Insurgent Violence Using Fuzzy Sets." Political Research Quarterly 62(4):673-684.

Metelits, Claire. 2010. Inside Insurgency: Violence, Civilians, and Revolutionary Group Behavior. New York University Press.

Persson, Torsten and Guido Tabellini. 2000. Political Economics: Explaining Economic Policy. MIT Press.

Restrepo, Jorge, Michael Spagat and Juan F. Vargas. 2004. "The Dynamics of the Colombian Civil Conflict: A New Data Set." Homo Oeconomicus 21:396-428.

Slim, Hugo. 2010. Killing Civilians: Method, Madness, and Morality in War. Columbia University Press.

Small Wars Manual: United States Marine Corps. 1940. United States Government Printing Office.

Smith, Rupert. 2005. The Utility of Force. Alfred A. Knopf. 
The U.S. Army/Marine Corps Counterinsurgency Field Manual. 2007. University of Chicago Press.

Tse-Tung, Mao. 1937. On Guerrilla Warfare. University of Illinois Press.

Valentino, Benjamin A., Paul K. Huth and Dylan Balch-Lindsay. 2004. "Draining the Sea: Mass Killing, Genocide, and Guerilla Warfare." International Organization 58.

Vargas, Juan F. 2009. "Military Empowerment and Civilian Targeting in Civil War." Documento de Trabajo No. 61, Facultad de Economia, Universidad del Rosario .

Weinstein, Jeremy M. 2006. Inside Rebellion: the Politics of Insurgent Violence. Cambridge University Press.

Wood, Reed. 2010. "Rebel Capability and Strategic Violence Against Civilians." Journal of Peace Research 47:601-614. 
Table 1: Summary Statistics

\begin{tabular}{|c|c|c|c|c|c|}
\hline Variable & Mean & Std. Dev. & Min. & Max. & $\mathbf{N}$ \\
\hline \multicolumn{6}{|l|}{ Dependent Variable } \\
\hline Civilian Casualties & 72.983 & 114.867 & 0 & 562 & 6,504 \\
\hline \multicolumn{6}{|l|}{ Training Variables } \\
\hline Generic Training & 0.854 & 0.353 & 0 & 1 & 6,658 \\
\hline Military Training & 0.851 & 0.356 & 0 & 1 & 6,713 \\
\hline Political Training & 0.771 & 0.42 & 0 & 1 & 6,713 \\
\hline \multicolumn{6}{|l|}{ Geographic Characteristics } \\
\hline Rainfall & $2,233.624$ & 875.007 & 761.462 & $5,643.684$ & 6,722 \\
\hline Water Availability & $3,471,714$ & 339,949 & $2,802,938$ & $4,433,159$ & 6,722 \\
\hline Elevation & 946.558 & 661.808 & 31.783 & 2,700 & 6,722 \\
\hline Area & $4,435,928$ & $2,629,555$ & 160,500 & $10,024,200$ & 6,722 \\
\hline Soil Quality & 2.707 & 0.632 & 0.356 & 4.059 & 6,722 \\
\hline Erosion & 1.891 & 0.488 & 0.018 & 3.004 & 6,722 \\
\hline \multicolumn{6}{|l|}{ Conflict Variables } \\
\hline Guerrilla Attacks & 42.673 & 53.467 & 0 & 243 & 6,504 \\
\hline Paramilitary Attacks & 11.255 & 17.56 & 0 & 81 & 6,504 \\
\hline Government Attacks & 11.098 & 13.393 & 0 & 51 & 6,504 \\
\hline Total Clashes & 43.536 & 46.94 & 0 & 170 & 6,504 \\
\hline Average Murder Rate & 72.845 & 36.526 & 0 & 167.451 & 5,191 \\
\hline \multicolumn{6}{|l|}{ Economic Attributes } \\
\hline Poverty Index & 48.545 & 13.647 & 9.16 & 88.658 & 6,722 \\
\hline Gini Coefficient & 0.673 & 0.088 & 0.373 & 0.799 & 5,511 \\
\hline \multicolumn{6}{|l|}{ Institutional Presence } \\
\hline Total Number of Courts & 0.822 & 0.231 & 0.209 & 1.734 & 4,068 \\
\hline Number of Prosecutors & 0.15 & 0.054 & 0.064 & 0.358 & 4,068 \\
\hline Number of Attorneys & 1.065 & 0.504 & 0.436 & 1.945 & 4,068 \\
\hline \multicolumn{6}{|l|}{ Dapartment Scale Control } \\
\hline Population & $2,064,318$ & $1,932,021$ & 0 & $6,840,116$ & 6,610 \\
\hline \multicolumn{6}{|l|}{ Individual Level Variables } \\
\hline Age of Entry Into Group & 20.388 & 7.188 & 5 & 54 & 6,722 \\
\hline FARC Dummy & 0.358 & 0.479 & 0 & 1 & 6,722 \\
\hline ELN Dummy & 0.081 & 0.273 & 0 & 1 & 6,722 \\
\hline AUC Dummy & 0.527 & 0.499 & 0 & 1 & 6,722 \\
\hline
\end{tabular}

Table 2: Cross-correlation table for training variables

\begin{tabular}{cccc}
\hline \hline Variables & Generic Training & Military Training & Political Training \\
\hline Generic Training & 1.000 & & \\
Military Training & 0.725 & 1.000 & \\
Political Training & 0.265 & 0.333 & 1.000 \\
\hline \hline
\end{tabular}


Table 3: Individually Reported Abuse, Goods Taken by Force

\begin{tabular}{|c|c|c|c|c|}
\hline Dependent variable: & $\begin{array}{c}\text { Goods Taken by } \\
(1) \\
\text { From Peasants }\end{array}$ & $\begin{array}{c}\text { Force } \\
\quad(2) \\
\text { From Merchants }\end{array}$ & $\begin{array}{c}(3) \\
\text { From Landowners }\end{array}$ & $\begin{array}{c}(4) \\
\text { From Any }\end{array}$ \\
\hline Generic Training & $\begin{array}{l}-0.0127 \\
(0.0115)\end{array}$ & $\begin{array}{r}-0.00117 \\
(0.0113)\end{array}$ & $\begin{array}{c}0.0132^{* * *} \\
(0.00387)\end{array}$ & $\begin{array}{r}-0.00172 \\
(0.0141)\end{array}$ \\
\hline \multicolumn{5}{|l|}{ Controls } \\
\hline Gender & $\checkmark$ & $\checkmark$ & $\checkmark$ & $\checkmark$ \\
\hline First group joined & $\checkmark$ & $\checkmark$ & $\checkmark$ & $\checkmark$ \\
\hline Age at recruitment & $\checkmark$ & $\checkmark$ & $\checkmark$ & $\checkmark$ \\
\hline Observations & 1,442 & 1,442 & 1,442 & 1,442 \\
\hline R-squared & 0.041 & 0.059 & 0.024 & 0.087 \\
\hline
\end{tabular}

Notes. Robust standard errors are shown in parentheses. ${ }^{* * *}$ is significant at the $1 \%$ level, ${ }^{* *}$ is significant at the $5 \%$ level, * is significant at the $10 \%$ level.

Table 4: Individually Reported Abuse, Goods Taken by Force

\begin{tabular}{|c|c|c|c|c|}
\hline Dependent variable & $\begin{array}{c}\text { Goods Taken by } \\
\text { (1) } \\
\text { From Peasants }\end{array}$ & $\begin{array}{c}\text { Force } \\
\quad(2) \\
\text { From Merchants } \\
\end{array}$ & $\begin{array}{c}(3) \\
\text { From Landowners }\end{array}$ & $\begin{array}{c}(4) \\
\text { From Any }\end{array}$ \\
\hline Military Training & $\begin{array}{l}-0.00736 \\
(0.0108)\end{array}$ & $\begin{array}{c}0.00947 \\
(0.00971)\end{array}$ & $\begin{array}{l}-0.00384 \\
(0.00908)\end{array}$ & $\begin{array}{r}-0.00890 \\
(0.0151)\end{array}$ \\
\hline \multicolumn{5}{|l|}{ Controls } \\
\hline Gender & $\checkmark$ & $\checkmark$ & $\checkmark$ & $\checkmark$ \\
\hline First group joined & $\checkmark$ & $\checkmark$ & $\checkmark$ & $\checkmark$ \\
\hline Age at recruitment & $\checkmark$ & $\checkmark$ & $\checkmark$ & $\checkmark$ \\
\hline Observations & 1,442 & 1,442 & 1,442 & 1,442 \\
\hline R-squared & 0.040 & 0.058 & 0.023 & 0.086 \\
\hline
\end{tabular}

Notes. Robust standard errors are shown in parentheses. ${ }^{* * *}$ is significant at the $1 \%$ level, ${ }^{* *}$ is significant at the $5 \%$ level, $*$ is significant at the $10 \%$ level. 
Table 5: Individually Reported Abuse, Goods Taken by Force

\begin{tabular}{lcccc}
\hline \hline Dependent variable: Goods Taken by Force & & & \\
& $(1)$ & $(2)$ & $(3)$ & $(4)$ \\
& From Peasants & From Merchants & From Landowners & From Any \\
\hline \multirow{2}{*}{ Political Training } & $-0.0253^{* *}$ & -0.0169 & 0.00385 & $-0.0320^{* *}$ \\
& $(0.0116)$ & $(0.0117)$ & $(0.00616)$ & $(0.0145)$ \\
& & & & \\
Controls & & $\checkmark$ & $\checkmark$ & $\checkmark$ \\
Gender & $\checkmark$ & $\checkmark$ & $\checkmark$ & $\checkmark$ \\
First group joined & $\checkmark$ & $\checkmark$ & $\checkmark$ & $\checkmark$ \\
Age at recruitment & $\checkmark$ & & & \\
& & 1,442 & 1,442 & 1,442 \\
Observations & 1,442 & 0.059 & 0.023 & 0.089 \\
R-squared & 0.044 & \multicolumn{4}{l}{} \\
\hline \hline
\end{tabular}

Notes. Robust standard errors are shown in parentheses. ${ }^{* * *}$ is significant at the $1 \%$ level, ${ }^{* *}$ is significant at the $5 \%$ level, $*$ is significant at the $10 \%$ level. 
Table 6: Generic Training

\begin{tabular}{|c|c|c|c|c|c|c|c|}
\hline Dependent variable: Civilio & $\begin{array}{c}n \text { Casual } \\
(1)\end{array}$ & $\begin{array}{c}\text { ies by } D \\
(2)\end{array}$ & $\begin{array}{c}\text { partment } \\
\text { (3) }\end{array}$ & $(4)$ & $(5)$ & $(6)$ & $(7)$ \\
\hline Generic Training & $\begin{array}{c}7.867^{* *} \\
(3.647)\end{array}$ & $\begin{array}{c}0.250 \\
(3.267)\end{array}$ & $\begin{array}{c}2.204^{* *} \\
(0.969)\end{array}$ & $\begin{array}{c}1.452 \\
(0.940)\end{array}$ & $\begin{array}{l}-0.083 \\
(0.908)\end{array}$ & $\begin{array}{c}0.187 \\
(0.885)\end{array}$ & $\begin{array}{c}0.515 \\
(0.911)\end{array}$ \\
\hline \multicolumn{8}{|l|}{ Controls by Department } \\
\hline Geography & & $\checkmark$ & $\checkmark$ & $\checkmark$ & $\checkmark$ & $\checkmark$ & $\checkmark$ \\
\hline Conflict variables & & & $\checkmark$ & $\checkmark$ & $\checkmark$ & $\checkmark$ & $\checkmark$ \\
\hline Poverty and Inequality & & & & $\checkmark$ & $\checkmark$ & $\checkmark$ & $\checkmark$ \\
\hline Institutional Presence & & & & & $\checkmark$ & $\checkmark$ & $\checkmark$ \\
\hline Population & & & & & & $\checkmark$ & $\checkmark$ \\
\hline Individual Characteristics & & & & & & & $\checkmark$ \\
\hline Observations & 6,440 & 6,440 & 5,138 & 5,138 & 3,026 & 3,026 & 3,026 \\
\hline R-squared & 0.001 & 0.215 & 0.959 & 0.962 & 0.977 & 0.979 & 0.979 \\
\hline
\end{tabular}

Notes. Robust standard errors are shown in parentheses. In column 2, geographic characteristics include the department's area, average elevation, average rainfall, soil quality and erosion, and an index of water availability. The conflict variables included in column 3 are the number of attacks from each armed group, the number of clashes between illegal groups and the government, and the average murder rate in the department. Column 4 includes the average of the Unsatisfied Basic Needs poverty index and the Gini coefficient. In column 5, the institutional presence variable is measured based on the department's total number of courts, attorney offices and prosecutor offices. In column 6, population is included as a municipal scale control. The individual characteristics included in column 7 are the age of the fighter, the age of recruitment, and the illegal group which the fighter belonged to. ${ }^{* * *}$ is significant at the $1 \%$ level, ${ }^{* *}$ is significant at the $5 \%$ level, $*$ is significant at the $10 \%$ level. 
Table 7: Military Training

\begin{tabular}{lccccccc}
\hline \hline \multicolumn{2}{c}{ Dependent variable: Civilian Casualties by Department } & & & & \\
& $(1)$ & $(2)$ & $(3)$ & $(4)$ & $(5)$ & $(6)$ & $(7)$ \\
\hline & & & & & & & \\
Military Training & $9.396^{* * *}$ & 2.013 & $2.121^{* *}$ & 1.079 & -0.699 & -0.356 & -0.104 \\
& $(3.630)$ & $(3.275)$ & $(0.941)$ & $(0.915)$ & $(0.914)$ & $(0.893)$ & $(0.929)$ \\
& & & & & & & \\
Controls by Department & & & & & & & \\
Geography & $\checkmark$ & $\checkmark$ & $\checkmark$ & $\checkmark$ & $\checkmark$ & $\checkmark$ \\
Conflict variables & & & $\checkmark$ & $\checkmark$ & $\checkmark$ & $\checkmark$ & $\checkmark$ \\
$\begin{array}{l}\text { Poverty and Inequality } \\
\text { Institutional Presence }\end{array}$ & & & & $\checkmark$ & $\checkmark$ & $\checkmark$ & $\checkmark$ \\
Population & & & & & $\checkmark$ & $\checkmark$ & $\checkmark$ \\
& & & & & & $\checkmark$ & $\checkmark$ \\
Individual Characteristics & & & & & & & $\checkmark$ \\
Observations & & & & & & & \\
R-squared & 6,495 & 6,495 & 5,184 & 5,184 & 3,046 & 3,046 & 3,046 \\
\hline \hline
\end{tabular}

Notes. Robust standard errors are shown in parentheses. In column 2, geographic characteristics include the department's area, average elevation, average rainfall, soil quality and erosion, and an index of water availability. The conflict variables included in column 3 are the number of attacks from each armed group, the number of clashes between illegal groups and the government, and the average murder rate in the department. Column 4 includes the average of the Unsatisfied Basic Needs poverty index and the Gini coefficient. In column 5, the institutional presence variable is measured based on the department's total number of courts, attorney offices and prosecutor offices. In column 6, population is included as a municipal scale control. The individual characteristics included in column 7 are the age of the fighter, the age of recruitment, and the illegal group which the fighter belonged to. *** is significant at the $1 \%$ level, ${ }^{* *}$ is significant at the $5 \%$ level, $*$ is significant at the $10 \%$ level. 
Table 8: Political Training

\begin{tabular}{|c|c|c|c|c|c|c|c|}
\hline \multicolumn{8}{|c|}{ Dependent variable: Civilian Casualties by Department } \\
\hline & $(1)$ & $(2)$ & $(3)$ & $(4)$ & $(5)$ & $(6)$ & $(7)$ \\
\hline Political Training & $\begin{array}{l}-5.493 \\
(3.379)\end{array}$ & $\begin{array}{c}-11.72^{* * *} \\
(3.052)\end{array}$ & $\begin{array}{l}-0.936 \\
(0.885)\end{array}$ & $\begin{array}{c}-1.770^{* *} \\
(0.847)\end{array}$ & $\begin{array}{c}-2.652^{* * *} \\
(0.807)\end{array}$ & $\begin{array}{c}-2.189 * * * \\
(0.779)\end{array}$ & $\begin{array}{r}-1.829^{* *} \\
(0.805)\end{array}$ \\
\hline \multicolumn{8}{|l|}{ Controls by Department } \\
\hline Geography & & $\checkmark$ & $\checkmark$ & $\checkmark$ & $\checkmark$ & $\checkmark$ & $\checkmark$ \\
\hline Conflict variables & & & $\checkmark$ & $\checkmark$ & $\checkmark$ & $\checkmark$ & $\checkmark$ \\
\hline Poverty and Inequality & & & & $\checkmark$ & $\checkmark$ & $\checkmark$ & $\checkmark$ \\
\hline Institutional Presence & & & & & $\checkmark$ & $\checkmark$ & $\checkmark$ \\
\hline Population & & & & & & $\checkmark$ & $\checkmark$ \\
\hline Individual Characteristics & & & & & & & $\checkmark$ \\
\hline Observations & 6,495 & 6,495 & 5,184 & 5,184 & 3,046 & 3,046 & 3,046 \\
\hline R-squared & 0.000 & 0.218 & 0.959 & 0.962 & 0.977 & 0.979 & 0.979 \\
\hline
\end{tabular}

Notes. Robust standard errors are shown in parentheses. In column 2, geographic characteristics include the department's area, average elevation, average rainfall, soil quality and erosion, and an index of water availability. The conflict variables included in column 3 are the number of attacks from each armed group, the number of clashes between illegal groups and the government, and the average murder rate in the department. Column 4 includes the average of the Unsatisfied Basic Needs poverty index and the Gini coefficient. In column 5, the institutional presence variable is measured based on the department's total number of courts, attorney offices and prosecutor offices. In column 6, population is included as a municipal scale control. The individual characteristics included in column 7 are the age of the fighter, the age of recruitment, and the illegal group which the fighter belonged to. ${ }^{* * *}$ is significant at the $1 \%$ level, ${ }^{* *}$ is significant at the $5 \%$ level, * is significant at the $10 \%$ level. 
Table 9: Political Training, Paramilitary Sub-Sample

\begin{tabular}{|c|c|c|c|c|c|c|c|}
\hline Dependent variable: Civilian Cas & $\begin{array}{l}\text { lalties by } \\
\text { (1) }\end{array}$ & $\begin{array}{c}\overline{\text { Departme }} \\
(2)\end{array}$ & (3) & $(4)$ & $(5)$ & $(6)$ & $(7)$ \\
\hline Political Training, Paramilitaries & $\begin{array}{r}9.670^{* *} \\
(4.302)\end{array}$ & $\begin{array}{l}-2.696 \\
(3.618)\end{array}$ & $\begin{array}{l}-0.775 \\
(1.065)\end{array}$ & $\begin{array}{r}-1.885^{*} \\
(1.014)\end{array}$ & $\begin{array}{c}-3.006^{* * *} \\
(0.924)\end{array}$ & $\begin{array}{c}-2.939 * * * \\
(0.901)\end{array}$ & $\begin{array}{c}-3.181^{* * *} \\
(0.903)\end{array}$ \\
\hline \multicolumn{8}{|l|}{ Controls by Department } \\
\hline Geography & & $\checkmark$ & $\checkmark$ & $\checkmark$ & $\checkmark$ & $\checkmark$ & $\checkmark$ \\
\hline Conflict variables & & & $\checkmark$ & $\checkmark$ & $\checkmark$ & $\checkmark$ & $\checkmark$ \\
\hline Poverty and Inequality & & & & $\checkmark$ & $\checkmark$ & $\checkmark$ & $\checkmark$ \\
\hline Institutional Presence & & & & & $\checkmark$ & $\checkmark$ & $\checkmark$ \\
\hline Population & & & & & & $\checkmark$ & $\checkmark$ \\
\hline Individual Characteristics & & & & & & & $\checkmark$ \\
\hline Observations & 3,582 & 3,582 & 2,819 & 2,819 & 1,820 & 1,820 & 1,820 \\
\hline R-squared & 0.001 & 0.328 & 0.961 & 0.965 & 0.981 & 0.982 & 0.982 \\
\hline
\end{tabular}

Notes. Robust standard errors are shown in parentheses. In column 2, geographic characteristics include the department's area, average elevation, average rainfall, soil quality and erosion, and an index of water availability. The conflict variables included in column 3 are the number of attacks from each armed group, the number of clashes between illegal groups and the government, and the average murder rate in the department. Column 4 includes the average of the Unsatisfied Basic Needs poverty index and the Gini coefficient. In column 5 , the institutional presence variable is measured based on the department's total number of courts, attorney offices and prosecutor offices. In column 6, population is included as a municipal scale control. The individual characteristics included in column 7 are the age of the fighter, the age of recruitment, and the illegal group which the fighter belonged to. ${ }^{* * *}$ is significant at the $1 \%$ level, ${ }^{* *}$ is significant at the $5 \%$ level, * is significant at the $10 \%$ level. 
Table 10: Interactions between Training and Reasons for Joining Among Paramilitary ExCombatants

\begin{tabular}{|c|c|c|c|c|}
\hline Dependent variable: Civilian Casualties by Dep & $\begin{array}{c}\text { artment } \\
(1)\end{array}$ & $(2)$ & $(3)$ & $(4)$ \\
\hline Political Training & $\begin{array}{c}-6.854^{* * *} \\
(2.139)\end{array}$ & $\begin{array}{c}-3.038^{* * *} \\
(0.917)\end{array}$ & $\begin{array}{c}-3.095^{* * *} \\
(0.910)\end{array}$ & $\begin{array}{l}-6.464^{* * *} \\
(2.162)\end{array}$ \\
\hline Promised Material Benefits & $\begin{array}{l}-1.307 \\
(1.818)\end{array}$ & & & $\begin{array}{c}-1.274 \\
(1.830)\end{array}$ \\
\hline Political Training*Promised Material Benefits & $\begin{array}{l}4.333^{*} \\
(2.323)\end{array}$ & & & $\begin{array}{l}4.117^{*} \\
(2.338)\end{array}$ \\
\hline Improve Colombia & & $\begin{array}{l}-1.928 \\
(5.076)\end{array}$ & & $\begin{array}{l}-1.779 \\
(5.108)\end{array}$ \\
\hline Political Training*Improve Colombia & & $\begin{array}{l}-2.110 \\
(5.890)\end{array}$ & & $\begin{array}{l}-1.848 \\
(5.849)\end{array}$ \\
\hline Revenge & & & $\begin{array}{c}0.885 \\
(5.352)\end{array}$ & $\begin{array}{c}1.208 \\
(5.371)\end{array}$ \\
\hline Political Training*Revenge & & & -4.310 & $\begin{array}{l}-3.980 \\
(7.374)\end{array}$ \\
\hline \multicolumn{5}{|l|}{ Controls by Department } \\
\hline Geography & $\checkmark$ & $\checkmark$ & $\checkmark$ & $\checkmark$ \\
\hline Conflict & $\checkmark$ & $\checkmark$ & $\checkmark$ & $\checkmark$ \\
\hline Poverty and Inequality & $\checkmark$ & $\checkmark$ & $\checkmark$ & $\checkmark$ \\
\hline Institutional Presence & $\checkmark$ & $\checkmark$ & $\checkmark$ & $\checkmark$ \\
\hline Population & $\checkmark$ & $\checkmark$ & $\checkmark$ & $\checkmark$ \\
\hline Individual Characteristics & $\checkmark$ & $\checkmark$ & $\checkmark$ & $\checkmark$ \\
\hline Observations & 1,820 & 1,820 & 1,820 & 1,820 \\
\hline R-squared & 0.982 & 0.982 & 0.982 & 0.982 \\
\hline
\end{tabular}

hline

Notes. Robust standard errors are shown in parentheses. Geographic variables include the department's area, average elevation, average rainfall, soil quality and erosion, and an index of water availability. Conflict variables are the number of attacks from each armed group, the number of clashes between illegal groups and the government, and the average murder rate in the department. Poverty and inequality variables are the average of the Unsatisfied Basic Needs poverty index and the Gini coefficient. The institutional presence variables are the department's total number of courts, attorney offices and prosecutor offices. Population is included as a municipal scale control. Individual characteristics iare the age of the fighter, the age of recruitment, and the illegal group which the fighter belonged to. ${ }^{* * *}$ is significant at the $1 \%$ level, ${ }^{* *}$ is significant at the $5 \%$ level, $*$ is significant at the $10 \%$ level. 
Figure 1: Combatant Activity in Colombia

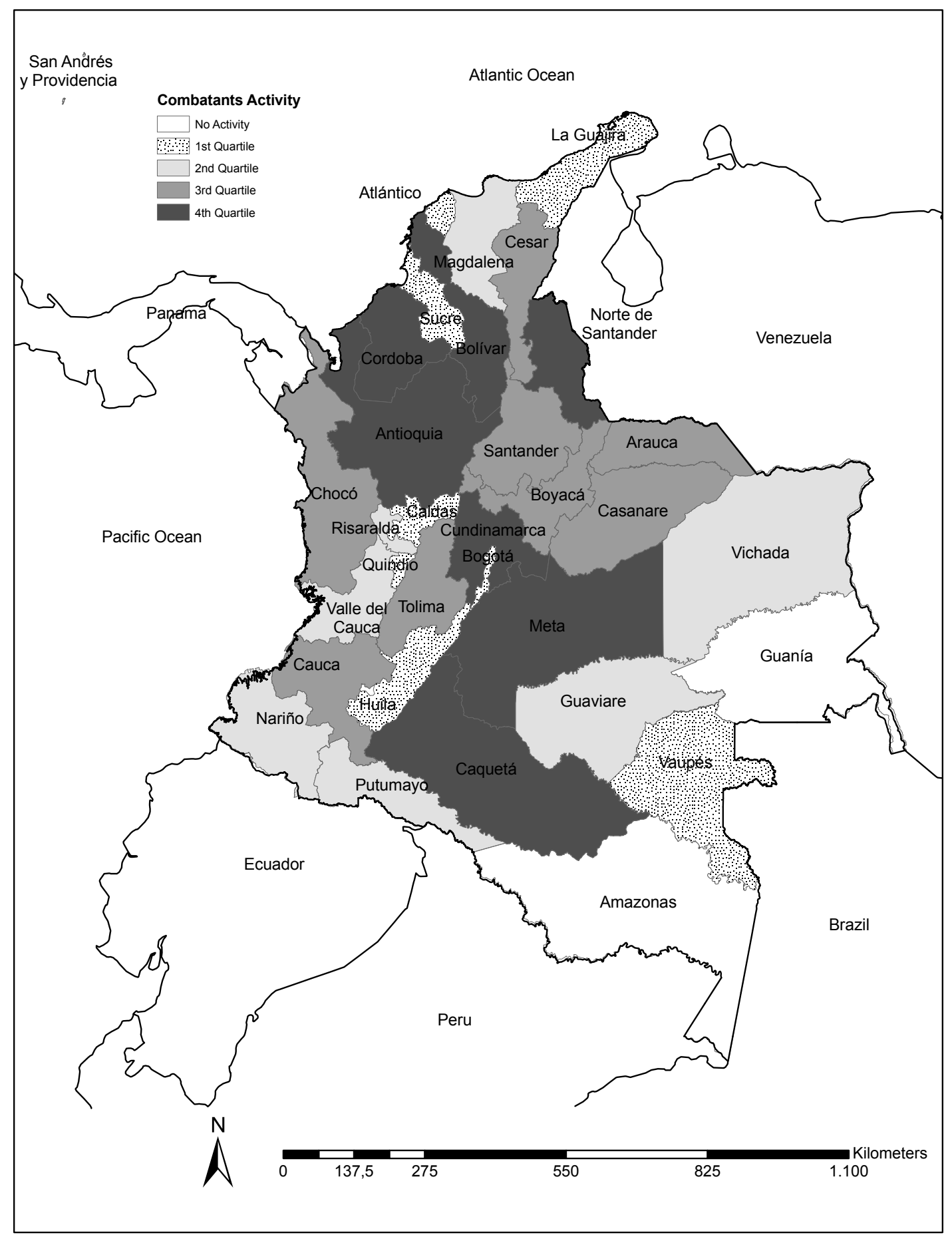


Figure 2: Civilian Victimization in Colombia

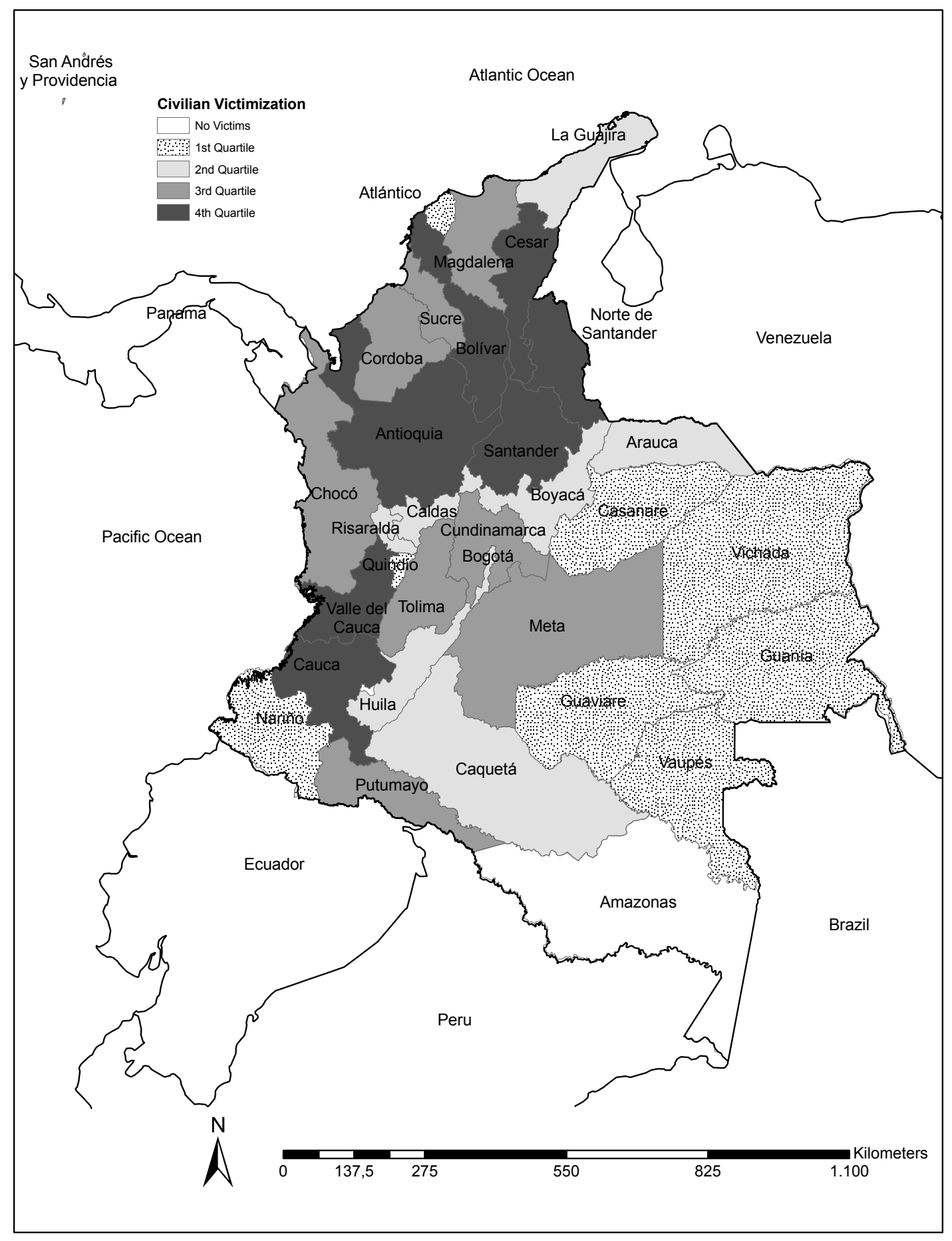


Figure 3: Frequency Histogram of Generic Training, By Group

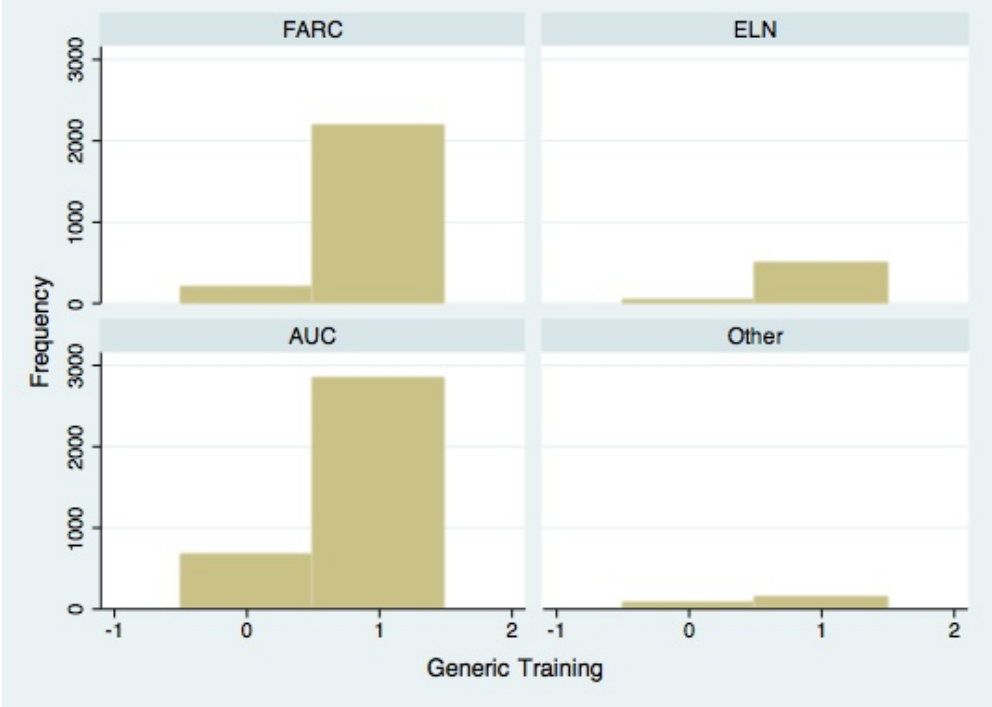

Figure 4: Frequency Histogram of Military Training, By Group

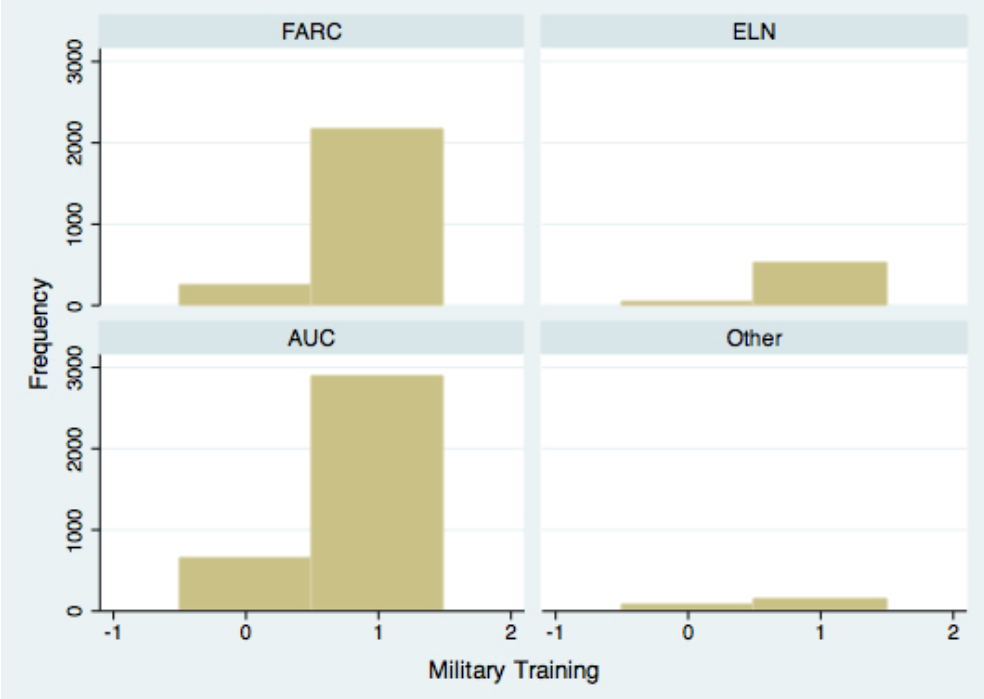


Figure 5: Frequency Histogram of Political Training, By Group

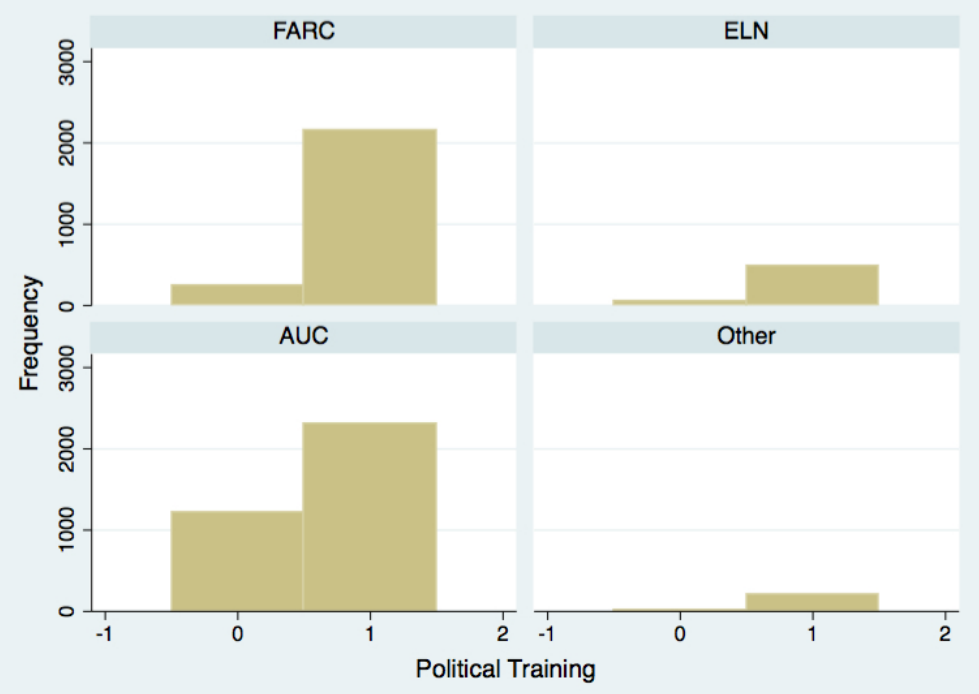

